\title{
Антропонимы тувинского языка, связанные с буддийской религией
}

\author{
Надежда Д. Сувандии \\ Тувинский государственный университет, Российская Федерация
}

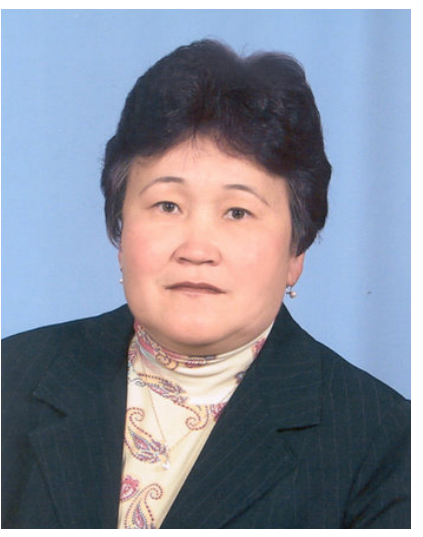

В статье представлена систематизация личных имен тувинцев, бытующих в настоящее время, связанных с буддийской религией, которые были заимствованы из тибетского языка и санскрита через монгольский. Материал исследования был собран автором во времена комплексных научных экспедиций в 1999-2020 г2. на территории Ховдского, Баян-Улэгэйского и Хубсугульского аймаков Монголии, а также в районах Республики Тыва.

Выделено восемь типов антропонимов: 1) антропонимы, связанные с названиями священных книг и текстами из сутр, которые используются при чтении молитв в буддийских монастырях; 2) личные имена, в которых отражены названия буддийских божеств; 3) имена, связанные с названиями планет; 4) антропонимы, характеризующие личностные качества и состояния денотата; 5) личные имена, связанные с атрибутикой священнослужителей; 6) имена, связанные с растительностью; 7) антропонимы, связанные с названиями драгоценных камней, металлов и др.; 8) антропонимы, связанные с различными достижениями служения буддизму. Приведены примеры по каждой из выделенных групп.

Также выявлены фонетические трансформации, которые встречаются почти во всех заимствованиях.

Ключевые слова: тувинский язык; ономастика; именник; личное имя; буддизм; лексико-семантическая группа; антропоним; заимствованное имя; тувинцы; Тува; Монголия; монгольские тувинцы

Работа выполнена при финансовой поддержке РФФИ в рамках научного проекта № 19-012-00073 «Трансформационные процессы в ономастике народов Центральной Азии: история и современность (на примере Тувы, Тофаларии, Калмыкии и Монголии)».

\section{Для цитирования:}

Сувандии Н. Д. Антропонимы тувинского языка, связанные с буддийской религией // Новые исследования Тувы. 2021, № 2. C. 44-51. DOI: https://www.doi.org/10.25178/nit.2021.2.4

Сувандии Надежда Дарыевна - кандидат филологических наук, декан филологического факультета Тувинского государственного университета. Адрес: 667004, Россия, г. Кызыл, ул. Педагогическая, д. 13. Тел.: +7 (923) 268-93-69. Эл. адрес: suvandiin@mail.ru

SUVANDII, Nadezhda Daryevna, Candidate of Philology, Dean, Philological Faculty, Tuvan State University. Postal address: 13 Pedagogicheskaya St., 667004 Kyzyl, Russian Federation. Tel.: +7(923) 268-93-69. E-mail: suvandiin@ mail.ru 


\title{
Buddhism-related Tuvan personal names
}

\author{
Nadezhda D. Suvandii \\ Tuvan State University, \\ Russian Federation
}

\begin{abstract}
The article aims to systematize contemporary Tuvan anthroponyms which are linked to Buddhism and were originally borrowed from Tibetan and Sanskrit via Mongolian language. The material presented here was collected by the author in the course of her comprehensive expeditions to Khovd, Bayan-Ölgii, and Khövsgöl aimags of Mongolia and some rayons of the Republic of Tuva.

As a result of our study, eight type of personal names have been identified: 1) anthroponyms stemming from the titles of the holy books and fragments of the sutras read during prayers in Buddhist monasteries; 2) personal names linked to the names of Buddhist deities; 3) those stemming from the names of the planets; 4) those repre-senting the personality and state of those they denote; 5) personal names stemming from words for accessories used by the clergy; 6) names linked to words for vegeta-tion; 7) anthroponyms formed from the roots meaning jewels, metals, etc.; and 8) personal names reflecting virtues of Buddhist worship. For each type, examples are provided in the article.
\end{abstract}

Also traced are the phonetical transformations which are manifest in almost any borrowed word.

Keywords: Tuvan language; onomastics; name list; personal name; Buddhism; lexical-semantic group; anthroponym; borrowed name; Tuvans; Tuva; Mongolia; Mongolian Tuvans

\begin{abstract}
Financing
The article was written with financial support from the RFBR as part of research project No. 19-012-00073 titled "Transformational processes in the onomastics of the peoples of Central Asia: history and modernity (the cases of Tuva, Tofalaria, Kalmykia and Mongolia)".
\end{abstract}

\section{For citation:}

Suvandii N. D. Antroponimy tuvinskogo iazyka, sviazannye s buddiiskoi religiei [Buddhism-related Tuvan personal names]. New Research of Tuva, 2021, no. 2, pp. 44-51. (In Russ.). DOI: https://www.doi.org/10.25178/nit.2021.2.4

\section{Введение}

Антропонимическая система каждого народа представляет собой ценный материал для ознакомления с его историей, культурой и языковыми особенностями. Также богата, разнообразна и показательна система личных имен тувинского народа.

Корни тувинских антропонимов восходят не только к тюркским языкам, но также к монгольским, тибетским и санскритским языкам. При этом личные имена монгольско-тибетского происхождения в основном связаны с буддийской религией, которая проникла в Туву через Монголию и укрепилась, стала государственной в XVIII в. (Монгуш, 2001). В возникновении антропонимов монгольско-тибетского происхождения немалую роль сыграли также одинаковый кочевой образ жизни и вид хозяйственной деятельности - скотоводство. Известный филолог Б. И. Татаринцев указывал, что общение между тувинцами и монголами осуществлялось в большинстве случаев на языке монголов, которым владела часть тувинского населения (Татаринцев, 1976: 9-11). Поскольку у тувинцев не было своей письменности, богатые тувинцы отправляли своих детей в Монголию, чтобы обучить их монгольской письменности. Также в буддийских монастырях Монголии обучение проходили и тувинские ламы.

Данные обстоятельства стали предпосылкой возникновения личных имен монгольско-тибетского происхождения в тувинской антропонимической системе. И в настоящее время в они составляют важную часть антропонимической системы. 
Тема личных имен монгольско-тибетского происхождения у тувинцев впервые появилась в капитальном труде Н. Ф. Катанова, где автор зафиксировал небольшое количество антропонимов: Адыјак - Адыяа (муж., жен.); Па̄зыр - Базыр (муж.); Ајыцы - Айыыжы (муж., жен.) и др. (Катанов, 1903). Один из первых исследователей тувинской антропонимической системы С. И. Вайнштейн в своих работах также рассматривал личные имена, которые попали в тувинский язык под влиянием буддизма (Вайнштейн, 1969). Он также подчеркнул, что имена, связанные с буддийской религией, попав в тувинский язык, под воздействием его фонетических законов изменили свой первоначальный облик (Вайнштейн, 1979). К. А. Бичелдей в своей работе, посвященной тувинскому языку, также упомянул тему личных имен тибетского, санскритского происхождения, заимствованных через монгольский язык, например Аранчын/ Эренчин - үнелиг - ‘ценный’, Базыр / Очур / Доржу - ‘алмаз', Дондук - угаанныг, билдилиг - ‘умный, волшебный’ и др. (Бичелдей, 1993). Ряд работ опубликовал Р. Д. Лудуп. Автор подчеркнул их специфичность для тувинской антропонимии, отличающей ее от других тюркских систем (Лудуп, 1996ab, 1997, 2017¹). В монографии М. В. Монгуш, одного из исследователей буддизма Тувы, также есть раздел, посвященный новшествам в имянаречении тувинцев, связанных с принятием новой религии (Монгуш, 2001: 159-161).

Автором данной статьи опубликована монография, в которой отдельной главой рассматриваются заимствованные из других языков личные имена, среди которых имеются и антропонимы, заимствованные из монгольского языка, через него из санскрита и тибетского (Сувандии, 2011) и статья по монгольско-тибетским именам (Сувандии, 2012).

В данной статье рассмотрено современное употребление у тувинцев личных имен монгольскотибетского происхождения, которое распространилось с момента возрождения буддизма в Туве в 1990-х гг. Источником исследования послужили личные имена, опубликованные в работах наших коллег, а также собранные автором во времена выездов в различные районы республики, также в научных экспедициях в 1999-2020 гг. в Монголию.

\section{Личные имена, связанные с буддизмом}

Проникновение буддизма в тувинскую культуру в том числе выразилось в наречении новыми именами детей тувинцев. Этот факт стал одним из показателей популяризации религии в народе. При этом популярность на современном этапе также связана с процессом религиозного возрождения, начавшимся в конце XX в. (Монгуш, 2001: 126-139).

Систематизация собранного нами материала позволила выявить в именах следующие лексикосемантические группы:

1.Антропонимы, связанные с названиями священных книг и текстами из сутр, которые используются при чтении молитв в буддийских монастырях. К подобным именам относятся Очуржап (тувинское имя, заимствованное, но подвергшееся фонетической трансформации - далее тув., муж.) - Очиржаб (санскритское - далее санскр., тибетское - далее тиб.) - защищенный алмазом; термин из текста сутры $^{2}$; Сундуй (тув., муж) ${ }^{3}-$ Сундуй (тиб.) - сборник священных текстов; Чадамба (тув.) - Жадамба (тиб.) - название священного текста (сутры) - название сокращенного варианта праджня-парамиты; Санчайжап (тув., муж.) - Санжайжаб (тиб.) - название текста из сутры и т. д.

Личные имена данной группы были и остаются востребованными, особенно в последнее время. В настоящее время большая часть верующих жителей республики по своим менги - 'знакупокровитель ${ }^{4}$ - читают тексты из сутр, названия которых могут быть личными именами;

2. Личные имена, в которых отражены названия буддийских божеств: Агбаан Агваан (тув., муж.) (Лудуп, 1996а) - Агван (тиб.) - имя бога Манджшури, владыки слова; Аюуш (тув., общее (и для мужчин, и для женщин) - далее общ.) - Аюш (там же) Аюуша (тув., жен.) Аюша (санскр.) - имя божества долголетия; продлителя жизни; Долчаң Долчаңмаа (тув., жен.) (там же) Дара (тув., жен.) - Должин

\footnotetext{
${ }^{1}$ См. также: Лудуп, Р. Д. (2001) Моол, төвүт, санскрит уктуг тыва антропонимнер [Тувинские антропонимы монгольского, тибетского и санскритского происхождения] : дипломная работа. Кызыл. 51 с. (На тув. языке).

${ }^{2}$ Информант: Сундуй Молам Борисович, 1996 г. р., г. Кызыл, Республики Тыва, священнослужитель.

${ }^{3} \mathrm{OH}$ же.

${ }^{4}$ Менги - знак-покровитель в тувинской культуре, который определяется по году, месяцу и дате рождения человека.
} 
(тиб.) Дара (санскр.) - название Зеленой Тары, зеленой освободительницы ${ }^{1}$; Долгар, Долгармаа (тув., жен.) - Долгор, Долгорма (тиб.) синоним Аюрзана Аюржана (санскр.) - название Белой Тары, освободительница; Комбу (тув., муж.) - Гомбо (тиб.) - имя божества-покровителя, защитника и хранителя веры; Найдан (тув., муж.) Найдаң (Лудуп, 1997) - Найдан (тиб.) - белый старец, наименование старшего возрастом, почитаемого монаха и т. д.

Личные имена, связанные с названиями буддийских божеств, встречаются почти в каждой семье верующих. Тувинцы считали, что божества буддийской веры оберегают их семьи. Поэтому они нарекали подобными именами своих детей. По словам информантов, в прежние времена, если в семье детей не было или они по каким-то болезням умирали, тувинцы ездили в Монголию, поклонялись Зеленой Таре, получали благословление и рожали детей ${ }^{2}$;

3. Имена, связанные с названиями планет. В антропонимах данной лексико-семантической группы кроме названий планет, также перечисляются и наименования дней недели: Даваа (тув., муж.) (Лудуп, 1996а) - Даваа Даба (тиб.) - 'горный перевал'; узкий горный переход (Большой академический ..., 2001a: 8); планета Луна, день недели - понедельник; Мыңмыр (тув., муж.) - Мягмар (тиб.) - планета Марс, день недели - вторник; Лакпа Лакпаа (тув., муж.) - Лхагва (тиб.) - I. 'громадный'; II. 1. планета Меркурий, 2. день недели - среда (Большой академический ..., 2001b: 306); Бурбу Пюрбю (тув., муж.) Пурбу (тиб.) - планета Юпитер, день недели - четверг; Баазаң (тув., муж.) (Лудуп, 1996а) - Баасан (тиб.) - планета Венера, день недели - пятница (Большой академический..., 2001а: 204); Бимба Бамба (тув., муж.) - Пимба Пенпа (тиб.) - планета Сатурн, день недели - суббота; Нима Ниман (тув., муж.) - Нима (санскр.) - планета Солнце, день недели - воскресениез

Личные имена названной лексико-семантической группы в современной системе личных имен являются распространенными в связи с тем, что многие современные родители перед наречением детей именем ходят к ламам, которые советуют дать им имена по характеру и названию дня неделич.

4. Антропонимы, характеризующие личностные качества и состояния денотата: Ананды (тув., муж.) - Ананда (санскр.) - радость, радостный; Балдаң (тув., муж.) (Лудуп, 1996) - Балдан (тиб.) великолепие, великолепный; Тагба Дагба (тув., муж.) - Дагба (тиб.) - чистый, безгрешный, очистившийся от пороков; Дондук (тув., муж.) (Лудуп, 1996) - Дондок (тиб.) - благонамеренность, благонамеренный; Калзан (тув., муж.) - Галсан (тиб.) - хорошая судьба; Кунгаа (тув., муж.) - Гунга (тиб.) радость, веселье; Делег (тув., муж.) - Дэлэг (тиб.) - покой, счастье ${ }^{5}$ и др.

Родители при наречении своих детей именами данной группы выражают свои пожелания, чтобы их чада в своей дальнейшей жизни имели в себе именно качества, отражающиеся в них. Следовательно, данные имена могут иметь смысл имен-пожеланий, как в собственно тувинских именах, которые содержат в себе пожелания хорошей, благополучной жизни своим детям во взрослой жизни. В древние времена тувинцы традиционно нарекали своих детей именами, которые имели в большей степени «отрицательные, непристойные» значения в связи с тем, что детей могли сглазить, например, Өктекоол - от өктек - 'кал', Чүдек - от чүдек - 'некрасивый’ и т. д. - с охранительными целями. Традиция наречения красивыми, звучными именами появились в тувинском языке во второй половине XX века.

5. Личные имена, связанные с атрибутикой священнослужителей: Анзат (тув., общ.) - Анзад (тиб.) сокровищница могущества - святой атрибут священнослужителей; Пурбу Бурбу (тув., муж.) - Пурба (тиб.) - ритуальный трехгранный кинжал для изгнания злых духов; атрибут священнослужителейб; Дамбыра (тув., муж.) - Дамбар (тиб.) - барабан; атрибут священнослужителейㄱ; Очур (тув., муж.) Очир (санскр.-тиб.) - алмаз; атрибут, означающий символ нерушимости учения тантризма ${ }^{8}$ и т. д.

\footnotetext{
${ }^{1}$ Информант: Сундуй Молам Борисович, 1996 г. р., г. Кызыл, Республики Тыва, священнослужитель.

${ }^{2}$ Информант: Монгуш Виктор Бойдуевич, 1943 г. р., с. Аянгаты, Барун-Хемчикского района Тувы, пенсионер.

${ }^{3}$ Информант: Монгуш Виктор Бойдуевич, 1943 г. р., с. Аянгаты, Барун-Хемчикского района Тувы, пенсионер.

${ }^{4}$ Информант: Ликчар Валентина Михаловна, 1958 г. в г. Чадан, Дзун-Хемчиксого района, Республики Тыва, индивидуальный предприниматель.

${ }^{5}$ Информант: Ооржак Сергек Михайлович, 1988 г. р., с. Теве-Хая, Дзун-Хемчикского района, священнослужитель буддийского храма Цеченлинг.

${ }^{6}$ Информант: Сагаан Аяс Яковлевича, 1979 г. р., с. Ак-Дуруг, Чаа-Холского района, священнослужителя буддийского храма Цеченлинг.

${ }^{7}$ Он же.

${ }^{8}$ Информант: Сундуй Молам Борисович, 1996 г. р., г. Кызыл, Республики Тыва, священнослужитель.
} 
Священнослужители буддийских храмов при проведении различных мероприятий, чтении мантр, проведении подношений используют различные атрибуты. Их названия стали использоваться для имен. По информации священнослужителей, подобные имена употреблялись в Тибете, Монголии, поэтому в тувинском языке данное явление является заимствованным из монгольского языка и через него из тибетского, в связи с чем, нет возражений по поводу их употребления в качестве личных имен.

6. К отдельной небольшой группе антропонимов относятся имена, связанные с растениями, значимыми для буддизма. В количественном отношении в тувинском языке они единичные, но употребляются в повседневной жизни часто: Бадыма (тув., жен.) - Бадма (санскр.) - лотос (цветок). Образ лотоса в буддизме символизирует непорочную чистоту, т. к. прекрасный лотос не имеет ничего общего с грязью болота, из которой он произрастает - также как Будда, достигший нирваны, вырвавшейся из болота сансары (Сотников, 2004: 4).

В современной тувинской антропонимической системе перечисленные имена употребляются часто, как подтверждают информанты-служители буддийских монастырей. Они являются священными растениями буддизма ${ }^{1}$.

7. Антропонимы монгольско-тибетского происхождения, связанные с названиями драгоценных камней, металлов и др., как и в исконно тувинских: Доржу (тув., муж.) - Доржо (тиб.) - алмаз, букв. 'князь камней’ (там же: 17), Дамба-Доржу (тув., муж.) - Дамбадорожо (тиб.) - священный алмаз; Норбу (тув., муж.) - Норбо (тиб.) - драгоценность (камни, металлы, кости священных животных и др.); Оюу Оюуна (тув., жен.) - Оюна (тиб.) - бирюза; Эренчин Эртине (тув., общ.) - Ринчин, Иринчин (тиб.) - драгоценность и т. д.

Слова, относящиеся к именам данной группы, в основном выражают общее название драгоценностей и названия камней, используемых для украшения атрибутики священнослужителей.

8. Среди заимствованных имен, связанных с буддизмом, отдельной группой нами выделены антропонимы, связанные с различными достижениями служения буддизму, например, Ендан (тув., муж.) Ендон (тиб.) - достоинство, добродетель; знание; Чымба (тув., муж.) - Жимба (тиб.) - подаяние, милостыня, пожертвование; щедрость одна из 6 парамит; Ойдуn, Ойдуn-оол (тув., муж.) - Ойдоб, Ойдоп (тиб.) - совершенство, способность, сиддхи, т. е. сверхъестественные способности силы человека, которые приобретены им в результате практики йоги르, Самдан (тув., муж.) - Самден (тиб.) - начальная стадия сосредоточения, медитации ${ }^{3}$; Содунам, Соднам (тув., муж.) - Содном (тиб.) - духовная заслуга, приобретаемая в результате совершения добродетельных поступков; Хорлуу (тув., общ.) - Хорло (тиб.) - колесо, круг; колесо 8 основных учений буддизма и др.

Таким образом, в тувинской системе личных имен антропонимы, заимствованные из монгольского и через него из других языков, в связи с проникновением буддизма в Туву, достаточно разнообразны. Выявленные в ходе исследования личные имена употреблялись в XIX в. и остаются восстребованными в настоящее время, за исключением периода с 40-х по конец 80-х годов XX столетия.

\section{Фонетические трансформации в тувинских личных именах}

Личные имена при переходе из одного языка в другой меняют свой фонетический облик. Причем эти изменения в современной системе личных имен подчиняются внутренним правилам орфоэпии - совокупности правил устной и письменной речи, закрепленных в литературном языке (Лингвистический энциклопедический ..., 1990).

В антропонимической системе тувинского языка, немалую часть которых составляют заимствованные личные имена как с монгольского, так и с русского, зафиксированы значительные фонетические изменения.

Основные фонетические процессы в области вокализма

1. В современном тувинском языке в словоформах с гласными я, e, ё, ю, обозначающих два звука [ŭa], [ŭэ], [ŭy], [ŭo], при долгом произношении в конце гласного добавляется соответствующий звук,

${ }^{1}$ Информант: Ооржак Сергек Михайлович, 1988 г. р., с. Теве-Хая, Дзун-Хемчикского района, священнослужитель буддийского храма Цеченлинг.

${ }^{2}$ Информант: Сундуй Молам Борисович, 1996 г. р., г. Кызыл, Республики Тыва, священнослужитель.

${ }^{3} \mathrm{OH}$ же. 
обозначающий долготу: Аюуша [Айууша] (тув.) - Аюша (тиб.), Аюур [Айуур] (тув.) - Аюр (тиб.); Оюу, Оюуна [Ойууна] (тув.) - Оюна (тиб.) и т. д.

2. В тувинском языке, как и в других тюркских языках, соблюдается гармония гласных - закон сингармонизма, т. е. уподобление гласных в последующих слогах и аффиксах какого-либо слова предшествующим гласным корня данного слова. В личных именах, заимствованных из монгольского и через него из тибетского, санскрита, часто функционирует данное явление: Должин (тиб.) - Долчаң (тув.) - по закону сингармонизма тувинского языка в первом слоге $\boldsymbol{o}-$ твердый гласный заднего ряда, последующий $\boldsymbol{u}$ - мягкий гласный переднего ряда уподобляется предыдущему и заменяется на $\boldsymbol{a}$; Самден (тиб.) - Самдан (тув.) - $\boldsymbol{a}$ - твердый гласный заднего ряда, последующий мягкий гласный $\boldsymbol{e}$ (э) уподобляется предыдущему и заменяется на $\boldsymbol{a}$; Очижжаб (санскр.-тиб.) - Очуржап (тув.) - мягкий гласный $\boldsymbol{u}$ во втором слоге по правилам сингармонизма тувинского языка заменяется на $\mathbf{y}$ и др.

3. В личных именах тувинского языка заимствованное с тибетского слово маа 'мать' употребляется в качестве аффикса женских имен -маа и произносится долго, пишется с двумя гласными: Долгор (тиб.) - Долгармаа (тув.), Дэнсэн Дэнсэма (тиб.) - Дензенмаа Дензинмаа (тув.), Норжон (тиб.) Норжунмаа (тув.) и т. д.

4. В некоторых личных именах монгольско-тибетского происхождения наблюдается явление эпентезы - вставка гласного внутри него: Бадма (тиб.) - Бадыма (тув.), Дансрун (тиб.) - Данзырын (тув.), Дарма (тиб.) - Дарыма (тув.), Содном (тиб.) - Содунам (тув.) и т. д.

5. Заимствованные из монгольского языка имена в языке-оригинале произносятся кратко и пишутся с одной гласной, а в тувинском языке появляется долгота, обозначающая двумя буквами: Даба, Даваа (тиб.) - Даваа (тув.), Даржа (тиб.) - Даржаа (тув.), Дэнсэма (тиб.) - Дензенмаа (тув.), Норжима (тиб.) Норжунмаа (тув.) и т. п.

\section{Фонетические процессы в области консонантизма}

1. В тувинском языке конце слова не употребляются звонкие согласные звуки. Следовательно, в тувинских личных именах, заимствованных с монгольского языка с конечным звонким, происходит оглушение: Анзад (тиб.) - Анзат (тув.), Гомбожаб (тиб.) - Комбужап (тув.), Дондуб (тиб.) - Дондуn (тув.), Мижид (тиб.) - Мижит (тув.), Намдаг (тиб.) - Намдак (тув.) и т. д.

2. В середине тувинских слов после звонких и сонорных не употребляются глухие согласные, что и встречается в заимствованных именах, связанных с буддизмом: Балсан (тиб.) - Балзан (тув.), Галсан (тиб.) - Калзан (тув.), Дансаран (тиб.) - Данзырын (тув.), Лубсан (тиб.) - Лопсан (тув.) и т. д.

3. В начале тувинского слова не употребляются звонкие согласные, которые зафиксированы в личных именах, связанных с буддийской религией: Гунга (тиб.) - Кунгаа (тув.), Жамбал (тиб.) - Чамбал (тув.), Зандан (санскр.) - Сандан (тув.), Цэдэн (тиб.) - Седен (тув.) и др.

4. В системе заимствованных имен наблюдается единичный антропоним, где происходит противоположное вышеописанному явление, которое в начале пишется глухой звук, когда в тувинском пишется звонкий: Пурбэ (тиб.) - Бүрбү (тув.).

Отсюда следует отметить, что фонетические изменения в заимствованных личных именах, связанных с буддизмом, наблюдаются почти в большей части зафиксированных нами антропонимов. Их фонетический облик почти теряет свой первостепенный вид.

\section{Заключение}

В тувинской антропонимической системе наблюдается очень много заимствованных личных имен, связанных с буддийской религией. Распространение и укрепление буддийской религии на территории Тувы существенно обогатило систему имянаречения тувинцев. В ходе исследования мы выявили восемь основных лексико-семантических групп антропонимов, связанных с названиями буддийских божеств, священных книг, с названиями атрибутов священнослужителей и т. д.

Почти во всех личных именах монгольско-тибетского происхождения встречается фонетическая трансформация, которая происходит по законам произношения и правописания слов в тувинском языке. В результате трансформации некоторые имена даже теряют свой первостепенный облик.

Следует отметить, что современные родители больше стали ходить к священнослужителям для получения совета при выборе имени и часто выбирать имена тибетского и монгольского происхождения, увязывая имянаречение с религией. Полагаем, что это свидетельствует и о возросшей религиознос- 
ти в регионе, и о желании родителей с помощью священных образов, терминов распространить свои благопожелания на детей и их судьбы. Дальнейшее их изучение поможет составлению антропонимических словарей тувинского и других тюркских языков. В целом вопрос выбора имен у современных тувинцев нуждается в отдельных исследованиях, в том числе социологических, культурологических.

\section{СПИСОК ЛИТЕРАТУРЫ}

Бичелдей, К. А. (1993) Тыва дыл болгаш чугаа культуразы [Тувинский язык и культура речи]. Кызыл : Тувинское книжное издательство. 103 с. (На тув. языке).

Большой академический монгольско-русский словарь (2001a) / под ред. А. Лувсандэндэва, Ц. Цэдэндамба. М. : Academia. Т. 1. А-Г. 536 с.

Большой академический монгольско-русский словарь (2001b) / под ред. А. Лувсандэндэва, Ц. Цэдэндамба. М. : Academia. Т. 2. Д-О. 536 с.

Вайнштейн, С. И. (1969) Личные имена, термины родства и прозвища у тувинцев // Ономастика / отв. ред. В. А. Никонов, А. В. Суперанская. М. : Наука. 261 с. С. 125-132.

Вайнштейн, С. И. (1979) Системы личных имен у народов мира // Справочник личных имен народов РСФСР / под ред. А. В. Суперанской. М. : Русский язык. 656 с. С. 197-210.

Катанов, Н. Ф. (1903) Опытъ изслъдованія урянхайскаго языка, съ указаніемъ главньйшихъ родственныхъ отношеній его къ другимъ языкамъ тюркскаго корня. Казань : Типо-литографія Императорскаго Казанскаго Университета. 1600 с.

Лингвистический энциклопедический словарь (1990) / отв. ред. В. Н. Ярцева. М. : Советская энциклопедия. 683 с.

Лудуп, Р. Д. (1996а) Адың-шолаң чажыттары [Тайны имени твоего] // Башкы. № 5. С. 88-90. (На тув. языке).

Лудуп, Р. Д. (1996b) Адың-шолаң чажыттары [Тайны имени твоего] // Башкы. № 6. С. 79-85. (На тув. языке).

Лудуп, Р. Д. (1997) Адың-шолаң чажыттары [Тайны имени твоего] // Башкы. № 6. С. 89-91. (На тув. языке).

Лудуп, Р. Д. (2017) Ваджраянская антропонимика тувинцев: историко-этнографические аспект // Вестник Бурятского государственного университета. Гуманитарные исследования Внутренней Азии. Вып. 2. С. $102-105$.

Монгуш, М. В. (2001) История буддизма в Туве. Новосибирск : Наука. 198 с.

Сотников, И. В. (2004) Бурятские имена. Иволгинск : Изд-во Буддийской академии «Даша Чойнхорлинга». 46 с.

Сувандии, Н. Д. (2011) Тувинская антропонимия. Кызыл : Редакционно-издательский отдел ТувГУ. 207 с .

Сувандии, Н. Д. (2012) Тувинские личные имена монгольско-тибетского происхождения // Сибирский филологический журнал № 1. С. 111-116.

Татаринцев, Б. И. (1976) Монгольское языковое влияние на тувинскую лексику. Кызыл : Тувинское книжное издательство. 129 с.

Дата поступления: 14.04.2021 2.

\section{REFERENCES}

Bicheldei, K. A. (1993) Tyva dyl bolgash chugaa kul'turazy [Tuvan language and culture of speech]. Kyzyl, Tuvan Book Publishing House. 103 p. (In Tuv.).

Bol'shoi akademicheskii mongol'sko-russkii slovar' [The Large Academic Mongolian-Russian Dictionary] (2001a): in 4 vols. / executive editor G. Ts. Piurbeev. Moscow, Academia. Vol. 1. 520 p. (In Russ.)

Bol'shoi akademicheskii mongol'sko-russkii slovar' [The Large Academic Mongolian-Russian Dictionary] (2001b): in 4 vols. / executive editor G. Ts. Piurbeev. Moscow, Academia. Vol. 2. 536 p. (In Russ.)

Weinstein, S. I. (1969) Lichnye imena, terminy rodstva i prozvishcha u tuvintsev [Personal names, kinship terms and nicknames among Tuvans]. In: Onomastika [Onomastics] / ed. by V. A. Nikonov and A. V. Superanskaia. Moscow, Nauka. 261 p. Pp. 125-132. (In Russ.).

Vainshtein, S. I. (1979) Sistemy lichnykh imen u narodov mira [Systems of personal names among the peoples of the world]. In: Spravochnik lichnykh imen narodov RSFSR [Handbook of personal names of the peoples of the Russian Soviet Federative Socialist Republic] / ed. by A. V. Superanskaya. Moscow, Russkii iazyk. 656 p. Pp. 197-210. (In Russ.).

Katanov, N. F. (1903) Opyt izsledovaniia uriankhaiskago iazyka, s ukazaniem glavneishikh rodstvennykh otnoshenii ego $k$ drugim iazykam tiurkskago kornia [An essay on the Uryanghai language, indicating the most important kinship ties between it and the other languages of the Turkic root]. St. Petersburg, Tipo-litografiia Imperatorskogo universiteta. 1600 p. (In Russ.).

Lingvisticheskii entsiklopedicheskii slovar' [A linguistic encyclopedia] (1990) / ed. by V. N. Iartsev. Moscow, Sovetskaia entsiklopediia. 683 p. (In Russ.).

Ludup, R. D. (1996a) Adyng-sholang chazhyttary [Secrets of your name]. Bashky, no. 5, pp. 88-90. (In Tuv.). 
Ludup, R. D. (1996b) Adyng-sholang chazhyttary [Secrets of your name]. Bashky, no. 6, pp. 79-85. (In Tuv.).

Ludup, R. D. (1997) Adyng-sholang chazhyttary [Secrets of your name]. Bashky, no. 6, pp. 89-91. (In Tuv.).

Ludup, R. D. (2017) Vadzhraianskaia antroponimika tuvintsev: istoriko-etnograficheskie aspekt [Vajrayanic anthroponomy of Tuvans: historical and ethnographic aspects]. Vestnik Buriatskogo gosudarstvennogo universiteta. Gumanitarnye issledovaniia Vnutrennei Azii, vol. 2, pp. 102-105.

Mongush, M. V. (2001) Istoriya buddizma v Tuve (vtoraya polovina VI - konets XX v.) [The History of Buddhism in Tuva (latter half of the 6th - late 20th cc.)]. Novosibirsk, Nauka. 200 p. (In Russ.).

Sotnikov, I. V. (2004) Buriatskie imena [Buryat names]. Ivolginsk, Izd-vo Buddiiskoi akademii «Dasha Choinkhorlinga». 46 p. (In Russ.).

Suvandii, N. D. (2011) Tuvinskaia antroponimiia [Tuvan anthroponymy]. Kyzyl, Editorial and Publishing Department of Tuvan State University Publishing house. 207 p. (In Russ.).

Suvandii, N. D. (2012) Tuvinskie lichnye imena mongol'sko-tibetskogo proiskhozhdeniia [Tuvan personal names of Mongolian and Tibetan origin]. Siberian Journal Of Philology, no. 1, pp. 111-116. (In Russ.).

Tatarintsev, B. I. (1976) Mongol'skoe yazykovoe vliyanie na tuvinskuyu leksiku [Mongolian language influence on the Tuvan lexicon]. Kyzyl, Tuvinskii nauchno-issledovatel'skii institut yazyka, literatury i istorii. 129 p. (In Russ.).

Submission date: 14.04 .2021 . 